\title{
Isolation and molecular identification of fungi causing stem rot disease in Bali's local legumes
}

\author{
Ni Made Susun Parwanayoni ${ }^{1 *}$, Dewa Ngurah Suprapta ${ }^{2}$, Nyoman Darsini $^{1}$, Sang Ketut Sudirga ${ }^{1}$ \\ ${ }^{1}$ Department of Biology, Faculty of Mathematics and Natural Sciences, Universitas Udayana \\ Jl. Raya Kampus UNUD, Bukit Jimbaran, South Kuta, Badung, Bali. Indonesia. 80361 \\ *Email: parwanayoni@unud.ac.id \\ ${ }^{2}$ Laboratory of Biopesticide, Faculty of Agriculture, Universitas Udayana \\ Jl. Raya Kampus UNUD, Bukit Jimbaran, South Kuta, Badung, Bali. Indonesia. 80361
}

\begin{abstract}
Efforts to improve food security in Indonesia, particularly Bali, need to be supported by improvements in cultivation techniques, including the management of pests and diseases. Meanwhile, legume crops are often attacked by stem rot diseases which potentially decrease production and leads to economic losses. This disease is generally caused by the soil-borne pathogenic fungus Sclerotium rolfsii or Athelia rolfsii. The macroscopic and microscopic morphologies of these two species are the same and difficult to distinguish, hence, molecular identification is needed to differentiate between the species. Therefore, this study aims to isolate and molecularly identify the fungi causing stem rot disease in local legume plants in Bali. The methods used include isolation of pathogenic fungi from legumes showing symptoms of stem rot disease, pathogenicity test, identification of isolates with the highest virulent levels, DNA extraction, DNA amplification by PCR and electrophoresis, ITS region sequencing and computer analysis sequences. The isolation procedure identified six fungal isolates coded SKT, SKB1, SKB2 SKB3, SKL and SKN isolates. SKT isolates had the highest virulence rate as indicated by the pathogenicity test of peanut plants. Furthermore, molecular identification results show that SKT isolate is Athelia rolfsii, a similar clade with the fungi sequences in GenBank with $100 \%$ bootstrap support.
\end{abstract}

Keywords: Athelia rolfsii; PCR; phylogeny analysis; Sclerotium rolfsii; soybeans and peanuts

Article History: Received 29 February 2021; Received in revised form 29 March 2021; Accepted 30 May 2021; Available online 30 June 2021

How to Cite This Article: Parwanayoni NMS, Suprapta DN, Darsini N, Sudirga SK. 2021. Isolation and molecular identification of fungi causing stem rot disease in Bali's local legumes. Biogenesis: Jurnal Ilmiah Biologi. vol 9(1): 73-80. doi: https://doi.org/10.24252/bio.v9i1.20426.

\section{INTRODUCTION}

Legume crops are often attacked by stem rot diseases which potentially decrease production and lead to economic losses (Devi et al., 2017; Parveen et al., 2017; Parwanayoni et al., 2019). According to the BPS (2020), Indonesia has continued to import soybeans for the past 20 years, hence, imported soybeans have dominated food processing of raw materials such as tempe. Meanwhile, stem rot disease in soybean plants occurs more rapidly during the rainy season and causes crop failure. This disease is mainly caused by soil-borne fungi, namely Sclerotium rolfsii or Athelia rolfsii (Darvin, 2013; Doley \& Jite, 2013; Adeleke, 2016). Symptoms of stem rot disease in legume plants include initially drooping of leaves close to the ground, while the branches become wilted and yellowish. Furthermore, the leaves slowly turn dark brown and sometimes fall from the plants prematurely, while the branches wither and also turn dark brown, and the lower trunk adjacent to the ground is covered with white mycelium and sclerotia growth (Karthikeyan et al., 2015; Paul et al., 2017; Nugroho et al., 2019).

A. rolfsii is the sexual (teleomorphic) form of $S$. rolfsii and this fungus has a defense structure called sclerotia, which last for a long time in the soil. Under suitable environmental factors, sclerotia germinate and infect its host plants (Thiessen \& Woodward, 2012; Shen et al., 2020). Furthermore, S. rolfsii or A. rolfsii survives in the soil in the form of sclerotia, and when a suitable host plant is found, it causes infection of the plant (Parmar et al., 2015; Kwon et al., 2017). These fungi cause major economic losses in agriculture, due to its defense structure, namely sclerotia which survive in the soil for years, thereby, making this pathogen difficult to control (Madhuri \& Gayathri, 2014; Guerra et al., 2015; Sneha et al., 2016). A. rolfsii produces an extracellular enzyme, namely cellobiose dehydrogenase 
$(\mathrm{CDH})$ used to penetrate the host plant, while $S$. rolfsii also produce six extracellular enzymes, including amylase, carboxymethyl cellulase, lipase, laccase, catalase and gelatinase which are used to infect plant tissues (Chaurasia et al., 2015; Elias et al., 2015; Sennoi et al., 2021). The macroscopic and microscopic morphology of the two species are the same and difficult to distinguish, hence, molecular identification is needed to differentiate between the species (Paul et al., 2017).

Our survey conducted in 2018, at several legumes planting centers (peanuts and soybeans) in four Bali regencies found that the highest percentage of stem rot diseases occurred in Badung 30\%, Klungkung 20\%, Buleleng $10 \%$, and $6 \%$ in Tabanan Regency. This data shows that stem rot disease in legumes is still high in Bali, therefore, there is need to determine the species causing disease in plants for precise and effective control implementation. Improper control leads to various consequences such as resistance to pathogens and environmental damage, therefore, molecular identification of species is needed to provide definite and accurate results. The species found in this study provides the basis for further research, particularly on the effectiveness of disease control.

\section{MATERIALS AND METHODS}

Isolation of pathogenic fungi. The fungi were isolated from the stems and roots of legume plants (soybeans and peanuts) which show symptoms of stem rot disease (Fig. 1). The sampling was carried out at the soybeans and peanuts planting center in four regencies in Bali including Badung, Tabanan, Buleleng and Klungkung. Stems and roots of legume plants showing symptoms of stem rot were first cleaned and rinsed with running and sterile water respectively, cut into $1 \mathrm{~cm}$. The samples were placed in the petri dish containing PDA media and then incubated at $25^{\circ} \mathrm{C}$ until a fungus colony grew around the pieces of the plant. Furthermore, the fungal colonies produced were purified by transferring to a new PDA media to obtain a pure culture and to observe the colony morphology and color as well as sclerotia size (Henuk et al., 2017; Yusnawan et al., 2019; Prihatiningsih et al., 2020; Sennoi et al., 2021).

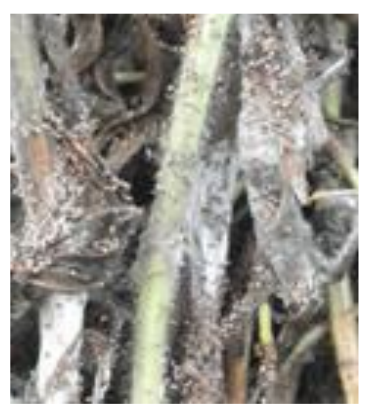

Fig. 1. Legume plants attacked by stem rot disease.

Pathogenicity test. The pathogenicity test was carried out to obtain the most virulent isolates using polybags filled with planting media. Before inoculating the isolates (pathogens) into the planting media, starch slurry potato was added with $3 \mathrm{~g}$ each. Furthermore, the samples were inoculated with pathogen isolates, and the peanut seeds were planted, meanwhile, symptoms of stem rot were observed 3 days after inoculation with the pathogen. The isolate with the fastest ability to cause symptoms of stem rot indicates the highest level of virulence. The isolates were then identified molecularly, to determine the species (Sana et al., 2017; Shen et al., 2020).

DNA extraction. DNA extraction was performed by first rejuvenating fungal isolates on PDA media for three days at room temperature $\left(25^{\circ} \mathrm{C}\right)$. Hyphae at the edges of the fungal colony were collected, placed into centrifuge bottles, and then suspended with 100 $\mu 1$ PrepMan Ultra Reagents (PrepMan Ultra Protocol, Applied Biosystem, USA). Furthermore, the samples were vortexed for 30 $s$ and then placed in a heat block temperature of $95^{\circ} \mathrm{C}-100^{\circ} \mathrm{C}$ for $10 \mathrm{~min}$ and at room temperature for $2 \mathrm{~min}$. The samples were further centrifuged at $10000 \mathrm{rpm}$ for $2 \mathrm{~min}$, while the pellets were collected as DNA extracts for further analysis. The DNA obtained was used as a template for amplification by the PCR (Polymerase Chain Reaction) method using primary pairs ITS 1 (primary forward) and ITS 4 (reverse primary) (Green \& Sambrook 2012).

DNA amplification. DNA amplification was performed on 18S rRNA Genes, with PCR 
using the Internal Transcript Spacer primer (ITS) 1 (5'-TCCGTAGGTGAACCTGCGG-3') and ITS 4 (5'-TCCTCCGCTTATTGATATGC3') with 600 bp PCR products. The reaction was carried out using the Takara PCR personal thermal cycler (Takara Bio, Otsu, Japan) with Ex Tag (Takara Bio, Otsu, Japan) under the following conditions; Pre-denaturation $94^{\circ} \mathrm{C}$ ( 4 $\min ), 35$ cycles of denaturation of $94^{\circ} \mathrm{C}(35 \mathrm{~s})$, annealing $52^{\circ} \mathrm{C}(55 \mathrm{~s})$, elongation $72^{\circ} \mathrm{C}(2 \mathrm{~min})$ and post elongation $72^{\circ} \mathrm{C}$ for $10 \mathrm{~min}$. Furthermore, the PCR results were visualized in $1 \%$ agarose gel and electrophoresed in trisacetic EDTA buffer (TAE), stained with nontoxic coloring (PeqGREEN). Electrophoresis was carried out at a voltage of 50 volts for 100 min, meanwhile, DNA amplification produced fragments measuring up to $600 \mathrm{bp}$. The DNA fragments produced were then sequenced to identify the fungus species (Iquebal et al., 2017).

ITS Region Sequencing. DNA sequences were determined using the BigDye Terminator Cycle Sequencing Ready Reaction Kit (Applied Biosystems, USA) and the PE Applied Biosystem Automated DNA Sequencer (model $3130 \times 1$, Applied Biosystems) according to the manufacturer's guidelines. The double helix DNA sequence was assembled and analyzed sequentially using genetyx (version 11.0) and genetyx-ATSQ (version 4.0) software (Genetyx, Japan), and compared with a similar sequence, from DDB/EMBL/GenBank via NCBI BLAST program. Furthermore, phylogeny analysis was performed using the MEGA 6.0 program, and the Maximum Parsimony (MP) method with a 1000x bootstrap, while the sequence data stored in a notepad with FASTA format were analyzed using the Blast-WU facility available online (Clustalw) at www.ebi.ac.uk, by comparing the similarities between sequences. The results obtained were then used as basic data to create phylogeny trees using MEGA data facilities (Sufaati et al., 2012; Tamura et al., 2013; Hanafiah et al., 2021).

\section{RESULTS AND DISCUSSION}

Isolation of pathogenic fungi. The isolation of pathogens causing stem rot disease in legumes produced six fungal isolates coded SKT, SKB1, SKB2, SKB3, SKL, and SKN. The SKT isolates were obtained from Klungkung Regency, SKB1, SKB2 and SKB3 from Badung Regency, SKL from Buleleng Regency and SKN from Tabanan Regency. Furthermore, the six fungal isolates were tested for pathogenicity and showed great potential for causing stem rot symptoms in peanut plants, but the virulence levels were different. The pathogenicity results are presented in Fig. 2.

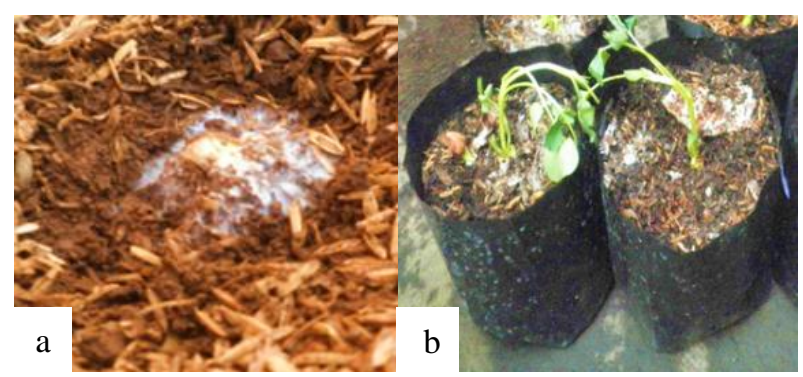

Fig. 2. Pathogenicity test results: a. SKT isolates with the highest virulence levels; b. other isolates.

The pathogenicity test results (Fig. 2) showed that SKT isolate had the highest virulence level, as indicated by the speed of stem rot disease symptoms appearance from the peanut plants, hence, this isolate was used for further testing. Symptoms of the disease appeared about two-four days after inoculation, with symptoms of peanut seeds being overgrown or colonized by fungi, thereby leading to rot and inability to germinate.

Characteristics of SKT isolate fungus. The macroscopic identification results showed that the SKT isolate in PDA media had characteristics such as white colony in the form of a cotton, mycelium with a fan-like structure, growth rate of $9.3 \mathrm{~mm} /$ day, thickening and folding of the mycelium after one week, formation of a sclerotia structure which is initially white with soft texture, but gradually turns dark brown with a hard texture. Furthermore, the sclerotia were shown on the PDA media after the isolate was 10-15 days old as presented in a plain view. The sclerotia were round with a diameter of $0.5-1 \mathrm{~mm}$ as shown in Fig. 3.

The $S$. rolfsii and $A$. rolfsii fungi have similar colony morphology when grown on PDA media, but both are distinguished by molecular identification (Srividya et al., 2017; 
Acabal et al., 2019). These two fungi are synonymous, $A$. rolfsii is a sexual (teleomorphic) form classified into the clas Basidiomycetes, while the asexual form (anamorphic) is $S$. rolfsii, classified into the class Deuteromycetes (Kwon et al., 2017). Furthermore, $S$. rolfsii in PDA media show a white feather-like colony and folds at the tip of the mycelia to form sclerotia after 6-10 days of incubation with a diameter of $0.5-2 \mathrm{~mm}$ (Daami-Remadi et al., 2012; Suheri et al., 2014). S. rolfsii fungi grown on different media showed different colony diameters during incubation for $72 \mathrm{~h}$, meanwhile, the PDA media produced the largest colony diameter and fastest growth (Muthukumar \& Venkatesh, 2013; Mahato \& Mondala, 2014). Moreover, the sclerotia diameter also differs, 1.5 and 1.7 $\mathrm{mm}$ in the PDA and Oatmeal media respectively (Banakar et al., 2017). Thiessen \& Woodward (2012) isolated Sclerotium from peanuts showing symptoms of stem rot disease and the number of sclerotia as well as sizes were also different. The four isolates showed variations in the size of the colony diameter (ranged from 90.1 to $90.5 \mathrm{~mm}$ ) and the number of sclerotia. Similarly, the number of sclerotia varied per petri dish with an incubation period of ten days.

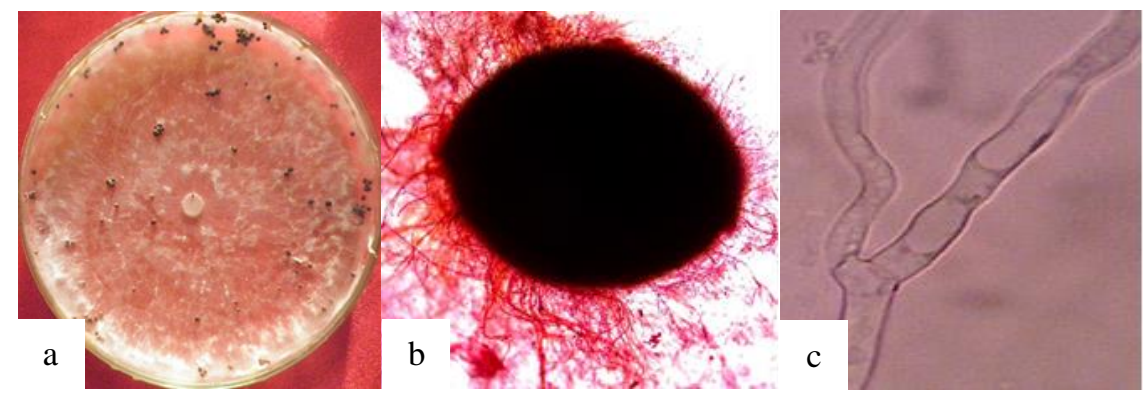

Fig. 3. The microscopic characteristics of SKT isolate: a. SKT isolate fungus on PDA media; b. Germinating sclerotia (magnification 10x); c. Microscopic characteristics of SKT isolate fungi: $1=$ branched hyphae, $2=$ septate hyphae (magnification 100).

The microscopic characteristics of SKT isolate including hyphal and sclerotia features observed using a light microscope (Fig. 3). These isolates have cylindrical hyphae and septa, as well as branched hyphae and clamp connections. Meanwhile, clamp connection in hyphae was observed microscopically after incubation for five days on PDA media. Ünal et al. (2017) stated that $S$. rolfsii has branched hyphae, clamp connection with a size of $10 \mu \mathrm{m}$, and sclerotia on the PDA media after 10 days of incubation with a diameter of 1-3 $\mathrm{mm}$. Furthermore, Zhou et al. (2014) observed that A. rolfsii had branched and insulated hyphae, while Nugroho et al. (2019) reported that the hyphae diameter of $S$. rolfsii isolates from Cucumis melo plants with symptoms of stem rot disease, ranged from 4-9 $\mu \mathrm{m}$ with clamp connections. Kwon et al. (2017) also examined ten isolates of Athelia spp. isolated from Ipomoea batatas showing symptoms of stem rot disease. The microscopic observation showed that the hyphae has a clamp connection, and the speed of mycelial colony growth on PDA media varied from 1.2-1.5 mm/day. In addition, the shape, color and size of the sclerotia also varied between isolates. The sclerotia size was observed macroscopically and the diameter was $0.5-2 \mathrm{~mm}$, while the colors ranged from light brown to dark brown, and the shapes were oval and round.

Molecular identification of SKT isolates.

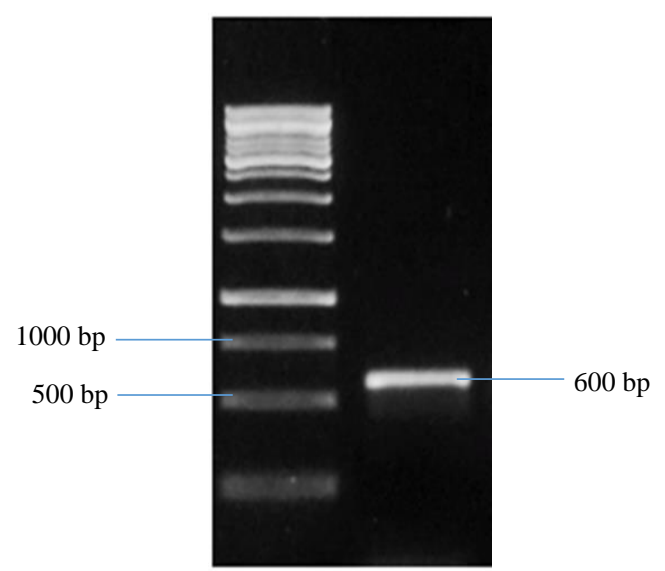

Fig. 4. PCR amplification of $18 \mathrm{~S}$ rRNA genes with ITS1 and ITS4 primers. 
The molecular identification of SKT isolates was carried out based on genetic analysis using primers that amplified internal transcribed spacer (ITS) $18 \mathrm{~S}$ rRNA genes, namely ITS 1 primer (F: 5'GGAAGTAAAAGTCGTAACAAGG-3') and ITS 4
(R: 5'-TCCTCCGCTTATTG ATATGC-3') which produced 600 bp DNA fragments (Fig. 4). The DNA fragments produced were purified and sequenced for identification based on similarities to other identified fungal species (Table 1).

Table 1 . The $18 \mathrm{~S}$ rRNA gene sequence for A. rolfsii.

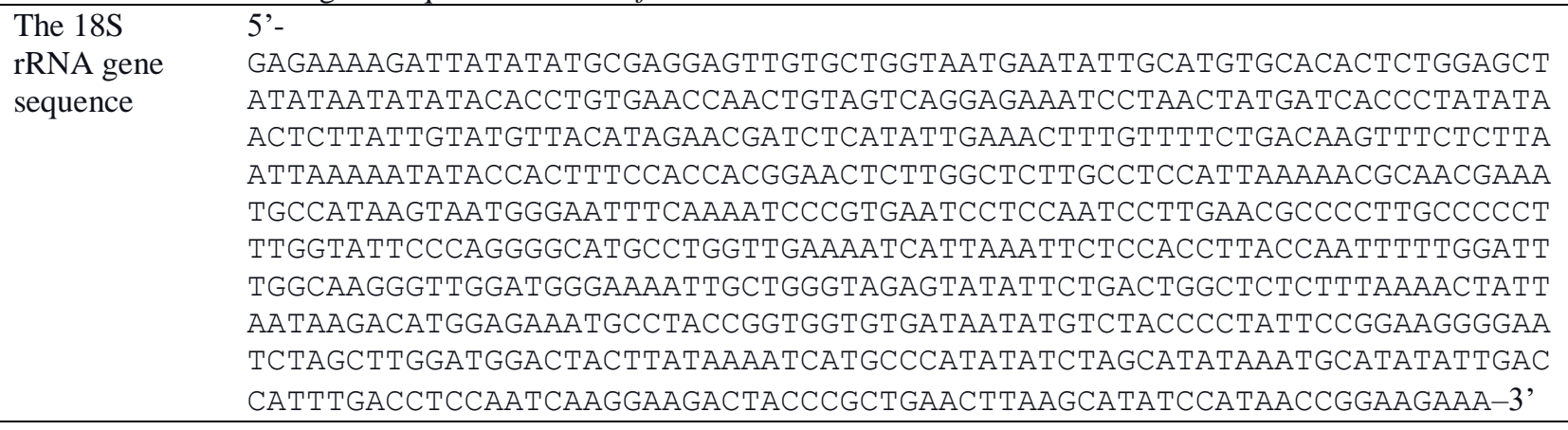

Table 2. Percentage of skill isolate SKT with some homological DNA sequences in GenBank based on $18 \mathrm{~s}$ rRNA gene sequences.

\begin{tabular}{|c|c|c|c|}
\hline No & Isolate & $\begin{array}{l}\% \text { of } \\
\text { similarity }\end{array}$ & $\begin{array}{l}\text { Accession } \\
\text { number }\end{array}$ \\
\hline 1 & $\begin{array}{l}\text { Athelia rolfsii } \\
\text { isolate SR2 }\end{array}$ & 98 & JN241555.1 \\
\hline 2 & $\begin{array}{l}\text { Athelia rolfsii } \\
\text { isolate BOScR1 }\end{array}$ & 98 & KJ546416.1 \\
\hline 3 & $\begin{array}{l}\text { Athelia rolfsii strain } \\
\text { SR1USVL }\end{array}$ & 98 & KU128903.1 \\
\hline 4 & $\begin{array}{l}\text { Athelia rolfsii } \\
\text { isolate AS } 1\end{array}$ & 98 & JN241563.1 \\
\hline 5 & $\begin{array}{l}\text { Athelia rolfsii } \\
\text { isolate } 3095\end{array}$ & 98 & JN241556.1 \\
\hline 6 & $\begin{array}{l}\text { Athelia rolfsii strain } \\
\text { A8 } 2\end{array}$ & 98 & GU08230.1 \\
\hline 7 & $\begin{array}{l}\text { Athelia rolfsii } 18 \mathrm{~S} \\
\text { Athelia rolfsii strain }\end{array}$ & 98 & DQ059578.1 \\
\hline 8 & $\begin{array}{l}\text { ATCC } \\
201126\end{array}$ & 98 & AF499018.1 \\
\hline 9 & $\begin{array}{l}\text { Athelia rolfsii } \\
\text { isolate } 176\end{array}$ & 98 & JN241564.1 \\
\hline 10 & $\begin{array}{l}\text { Athelia rolfsii } \\
\text { isolate } 3083\end{array}$ & 98 & JN241562.1 \\
\hline 11 & $\begin{array}{l}\text { Athelia rolfsii } \\
\text { isolate SR001 }\end{array}$ & 98 & HQ420816.1 \\
\hline
\end{tabular}

Based on the sequence alignment results and the homologous sequences available at GenBank using the BlastN program, the SKT isolates belong to the group $A$. rolfsii isolate SR2 (JN241555.1), A. rolfsii isolate BOScR1 (KJ546416.1), A. rolfsii strain SR1USVL (JN241555.1), A. rolfsii isolate BOScR1 (KJ546416.1), A. rolfsii strain SR1USVL (JN241555.1), A. rolfsii isolate BOScR1
(KJ546416.1), A. rolfsii strain SR1USVL (JN241555.1) KU128903.1), A. rolfsii isolate AS 1 (JN241563.1), A. rolfsii isolate 3095 (JN241556.1), $\quad$ A. rolfsii strain A8 2 (GU080230.1), A. rolfsii 18S (DQ059578.1), A. rolfsii strain ATCC 201126 (AF499018.1), A. rolfsii isolate 176 (JN241564.1), A. rolfsii isolate 3083 (JN241562.1), A. rolfsii isolate SR001 (HQ420816.1) with a maximum identity level of $98 \%$ (Table 2).

The phylogeny tree analysis using the Maximum Parsimony (MP) method with 1000 bootstrap replications showed that the SKT isolate was A. rolfsii, because it was in one clade with the $A$. rolfsii mushroom sequences in GenBank with $100 \%$ bootstrap support as shown in Fig 5. Based on molecular identification, the SKT fungus isolates obtained from legume plants showing symptoms of stem rot is A. rolfsii. Meanwhile, Kwon et al. (2017) reported that the phylogeny tree analysis showed that Athelia sp. and other Basidiomycetes members are divided into three clusters or groups namely S1, S2 and S3 clusters. A. rolfsii, $S$. rolfsii, Sclerotium delphinii and Sclerotium coffeicola are in the same cluster namely S3 which is the biggest cluster with a bootstrap value of $100 \%$, while Sclerotium denigrans, Sclerotium cepivorum, Sclerotinia sclerotiorum and Sclerotium perniciosum are grouped into cluster S1 along with Monilinia fructicola and Botryotinia fuckeliana with $97 \%$ bootstrap values. 
Furthermore, Sclerotium hydrophilum, Sclerotium rhizodes, Thanatephorus cucumeris and Ceratorhiza oryzae-sativae are grouped in cluster S2 with a bootstrap value of $96 \%$.

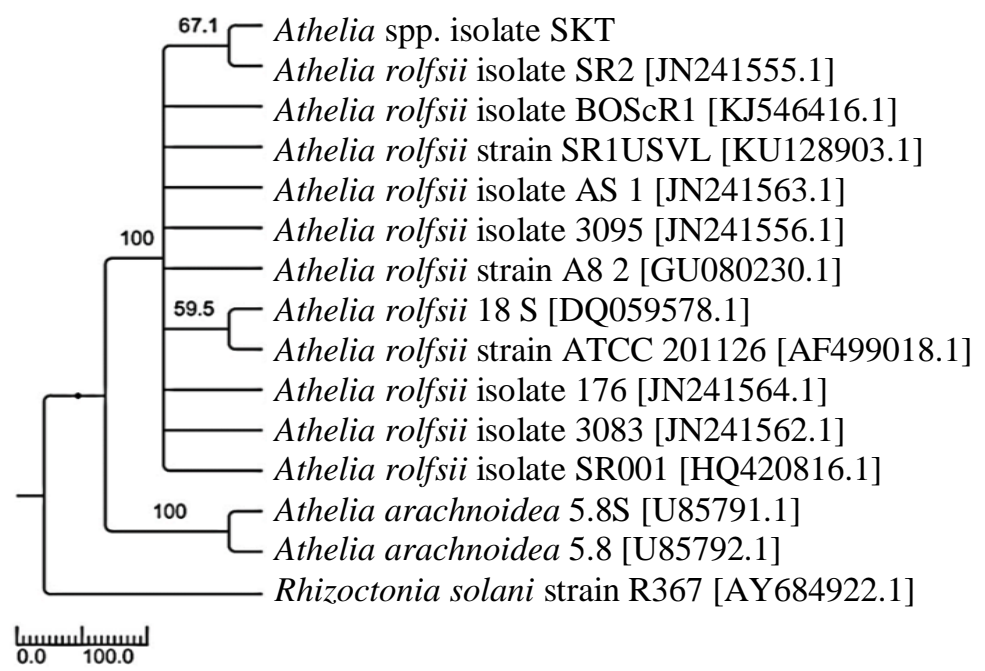

Fig. 5. The phylogeny tree was based on the maximum parsimony (MP) method for 18S rRNA gene sequences which showed a relationship between SKT isolates and fungi in GenBank. Bootstrap value (\%) is based on 1000 replications.

Hanafiah et al. (2021) on the phylogenetic relationship of class Basidiomycetes and ordo Atheliales including Athelia arachnoidea (AF518601), Athelia decipiens (AY586632) and Athelia epiphylla (AY586633), showed that the DNA sequences were in one clade in the GenBank database with $98 \%$ bootstrap support. Furthermore, Nugroho et al. (2019) reported that the phylogenetic analysis of Athelia spp. ITS sequence with Sclerotium delphinii and Sclerotium coffeicola form one cluster with $99 \%$ bootstrap support. S. rolfsii MHGNU F117 from Cucumis melo (KU760983) is in a similar clade with fungi sequences (KP257582), S. rolfsii KACC47819 from Momordica charantia, (HM355751), S. rolfsii KACC42087 from Hosta plantaginea, (K259782), and Catharanthus roseus in the GenBank database with $92 \%$ bootstrap support, and also with (AB075316) Sclerotium delphinii 196 from Lycopus sp. with 83\% bootstrap support as well as Athelia epiphylla with $60 \%$ bootstrap support.

\section{CONCLUSION}

The isolate of pathogens causing stem rot disease in Bali's local legume plants produced six fungal isolates coded SKT, SKB1, SKB2, SKB3, SKL and SKN isolates. SKT isolates had the highest virulence rate based on the pathogenicity test of peanut plants. Meanwhile, molecular identification shows that this isolate is Athelia rolfsii, because it is in a similar clade with Athelia rolfsii fungi sequences in GenBank with $100 \%$ bootstrap support.

\section{ACKNOWLEDGEMENTS}

The authors would like to thank the Laboratory of Microbiology, Department of Biology, Faculty of Mathematics and Natural Sciences, Bogor Agricultural University and Laboratory of Biopesticide, Faculty of Agriculture, Universitas Udayana, Bali, Indonesia.

\section{REFERENCES}

Acabal BD, Dalisay TU, Groenewald JZ, Crous PW, Cumagun CJR. 2019. Athelia rolfsii (= Sclerotium rolfsii) infects banana in the Philippines. Australasian Plant Disease Notes. vol 14: 1-10. doi: https://doi.org/10.1007/s13314-019-0341-x.

Adeleke MTV. 2016. Effect of Allium sativum (garlic) extract on the growth and nodulation of cowpea (Vigna unguiculata) and groundnut (Arachis hypogea). African Journal of Agricultural Research. vol 11(43): 4304-4312. doi: https://doi.org/10.5897/AJAR2016.11208.

Banakar SN, Kumar VBS, Thejesha AG. 2017. Morphological and cultural studies of Sclerotium rolfsii Sacc. causing foot rot disease of tomato. International Journal of Current Microbiology and Applied Sciences. vol 6(3): 1146-1153. doi: http://dx.doi.org/10.20546/ijcmas.2017.603.133.

BPS. 2020. Impor kedelai menurut negara asal utama, 2010-2020. Jakarta: Badan Pusat Statistik, 
Indonesia. https://www.bps.go.id/.

Chaurasia SC, Chaurasia AK, Chaurasia S, Chaurasia S. 2015. Factors affecting the production of poly methyl galacturonase enzyme by Sclerotium rolfsii Sacc. International Journal of Applied Sciences and Biotechnology. vol 3(1): 89-95. doi: https://doi.org/10.3126/ijasbt.v3i1.12200.

Daami-Remadi M, Jabnoun-Khiareddine H, Sdiri A, Mahjoub ME. 2012. Comparative reaction of potato cultivars to Sclerotium rolfsii assessed by stem rot and tuber decay severity. Pest Technology. vol 6(1): 54-59.

Darvin G. 2013. Effect of plant extracts on radial growth of Sclerotium rolfsii Sacc. causing stem rot of groundnut. International Journal of Applied Biology and Pharmaceutical Technology. vol 4(4): 69-73.

Devi KB, Pavankumar P, Bhadraiah B. 2017. Antifungal activity of plant extracts against post-harvest fungal pathogens. International Journal of Current Microbiology and Applied Sciences. vol 6(1): 669679.

doi: http://dx.doi.org/10.20546/ijcmas.2017.601.081.

Doley K, Jite PK. 2013. Management of stem-rot of groundnut (Arachis hypogaea L.) cultivar in field. Notulae Scientia Biologicae. vol 5(3): 316-324. doi: https://doi.org/10.15835/nsb538895.

Elias A, Ferreira ABM, Bueno CJ. 2015. In vitro production of extracellular enzymes by fungi and their relationship with the symptoms described for the host plant. Summa Phytopathol. vol 41(4): 315 317. doi: https://doi.org/10.1590/0100-5405/2044.

Green MR, Sambrook J. 2012. Molecular cloning: a laboratory manual (Fourth edition). New York: Cold Spring Harbor Laboratory Press. pp 81-87.

Guerra YDL, de Oliveira TAS, Laranjeira D, Lima LM, Filho PDAM, dos Santos RC. 2015. Control of Sclerotium rolfsii in peanut by using Cymbopogon martinii essential oil. African Journal of Microbiology Research. vol 9(27): 1684-1691. doi: https://doi.org/10.5897/AJMR2015.7574

Hanafiah DS, Safni I, Siregar LAM, Damanik RIM, Lestami A. 2021. Genetic analysis of soybean mutant lines resistance to stem rot disease (Athelia rolfsii Curzi). SABRAO Journal of Breeding and Genetics. vol 53(1):126-138.

Henuk JBD, Sinaga MS, Hidayat SH. 2017. Morphological and molecular identification of fungal pathogens causing gummosis disease of Citrus spp. in Indonesia. Biodiversitas Journal of Biological Diversity. vol 18(3): 1100-1108. doi: https://doi.org/10.13057/biodiv/d180330.

Iquebal MA, Tomar RS, Parakhia MV, Singla D, Jaiswal S, Rathod VM, Padhiyar SM, Kumar N, Rai A, Kumar D. 2017. Draft whole genome sequence of groundnut stem rot fungus Athelia rolfsii revealing genetic architect of its pathogenicity and virulence. Scientific Reports. vol 7: 1-10. doi: https://doi.org/10.1038/s41598-017-05478-8.

Karthikeyan P, Panneerselvam A, Senthilkumar G. 2015.
In vitro antifungal activity of actinobacteria against paddy fungal pathogens Athelia rolfsii and Cochliobolus lunatus. World Journal of Pharmaceutical Research. vol 4(2): 663-672.

Kwon JH, Kang DW, Hhan I, Shim CK, Kim J. 2017. Morphological and molecular characterization of Sclerotium rolfsii (teleomorph Athelia rolfsii) associated with sclerotium rot of Cucumis melo L. var. makuwa Makino. Journal of Agriculture \& Life Science. vol 51(2): 1-8.

Madhuri V, Gayathri DA. 2014. Root rot of chilli incited by Sclerotium rolfsii Sacc. and its management-a review. International Journal of Applied Biology and Pharmaceutical Technology. vol 5 (1): 197204.

Mahato A, Mondal B. 2014. Sclerotium rolfsii: its isolates variability, pathogenicity and an ecofriendly management option. Journal of Chemical, Biological and Physical Sciences. vol 4(4): 33343344.

Muthukumar A, Venkatesh A. 2013. Physiological studies of Sclerotium rolfsii Sacc. causing collar rot of peppermint. African Journal of Biotechnology. vol 12(49): 6837-6842.

Nugroho CE, Mirnia E, Cumagun CJR. 2019. Antifungal activities of sweet basil (Ocimum basilicum L.) aqueous extract against Sclerotium rolfsii, causal agent of damping-off on tomato seedling. Agrivita Journal of Agricultural Science. vol 41(1): 149157. http://doi.org/10.17503/agrivita.v41i1.1920.

Parmar HJ, Hassan MM, Bodar NP, Umrania VV, Patel $\mathrm{SV}$, Lakhani HN. 2015. In vitro antagonism between phytopathogenic fungi Sclerotium rolfsii and Trichoderma strains. International Journal Applied Sciences and Biotechnology. vol 3(1): 1619. doi: https://doi.org/10.3126/ijasbt.v3i1.11845.

Parveen S, Wani AH, Bhat MY, Malik AR, Koka JA, Ashraf N. 2017. Antimycotic potential of some phytoextracts on some pathogenic fungi. Journal of Biopesticides. vol 10(1): 60-65.

Parwanayoni NMS, Suprapta DN, Khalimi K. 2019. Synergistic effectivity of Mansoa alliacea and Allamanda cathartica leaf extracts controlling stem rot disease in peanut plant (Arachis hypogaea) at the greenhouse. IOP Conference Series: Earth and Environmental Science. vol 347: 1-5. doi: https://doi.org.10.1088/1755-1315/347/1/012077.

Paul NC, Eom-Ji H, Nam SS, Lee HU, Lee JS, Yu GD, Kang YG, Lee KB, Go S, Yang JW. 2017. Phylogenetic placement and morphological characterization of Sclerotium rolfsii (Teleomorph: Athelia rolfsii) associated with blight disease of Ipomoea batatas in Korea. Mycobiology. vol 45(3): 129-138.

doi: https://doi.org/10.5941/MYCO.2017.45.3.129.

Prihatiningsih N, Djatmiko HA, Lestari P. 2020. Screening of competent rice root endophytic bacteria to promote rice growth and bacterial leaf blight disease control. Jurnal Hama dan Penyakit 
Tanaman Tropika. vol 20(1): 78-84. doi: https://doi.org/10.23960/j.hptt.12078-84.

Sana N, Shoaib A, Javaid A. 2017. Management of collar rot disease in chili by farmyard manure and commercial biofertilizers. Sains Malaysiana. vol 46(10): 1693-1700. doi: http://dx.doi.org/10.17576/jsm-2017-4610-04.

Sennoi R, Jogloy S, Gleason ML. 2021. Development of an oxalic acid assay to evaluate Sclerotium rolfsii resistance in Jerusalem artichoke. SABRAO Journal of Breeding \& Genetics. vol 53(1): 70-78.

Shen YM, Lin YJ, Hsu CC, Huang TC. 2020. Athelia rolfsii infects dichondra in Taiwan. Journal Plant Medicine. vol 62(1): 21-28. doi: https://doi.org/10.6716/JPM.202003_62(1).0003.

Sneha S, Maurya S, Choudhary AK. 2016. Antifungal efficacy of garlic and ginger against Sclerotium rolfsii. International Journal of Agricultural Science and Research. vol 6(6): 419-424.

Srividya PV, Ahamed ML, Ramana JV, Ahmmed SK.2018. Characterization of Sclerotium rolfsii Sacc. causing collar rot in chickpea isolates using cultural and morphological traits. International Journal of Current Microbiology and Applied Sciences. vol 7(6): 3912-3922. doi: https://doi.org/10.20546/ijcmas.2018.706.462.

Sufaati S, Agustini V, Suharno S. 2012. Isolation and phylogenetic relationship of orchid-mycorrhiza from Spathoglottis plicata of Papua using mitochondrial ribosomal large subunit (mt-Ls) DNA. Biodiversitas Journal of Biological and Diversity. vol 13(2): 59-64. doi: https://doi.org/10.13057/biodiv/d130202.

Suheri H, Isnaini M, Rohyadi A. 2014. Application of organic amendment and Trichoderma sp. to control basal Sclerotium rolfsii on peanut grown on partially degraded land. Journal of Degraded and Mining Lands Management. vol 1(3): 131-136. doi: https://doi.org/10.15243/jdmlm.2014.013.131.

Tamura K, Stecher G, Peterson D, Filipski A, Kumar S. 2013. MEGA6: molecular evolutionary genetics analysis version 6.0. Molecular Biology and Evolution. vol 30(12): 2725-2729. doi: https://doi.org/10.1093/molbev/mst197.

Thiessen LD, Woodward JE. 2012. Diseases of peanut caused by soilborne pathogens in the Southwestern United States. International Scholarly Research Networkvol. $\quad$ vol 2012: 1-9. doi: https://doi.org/10.5402/2012/517905.

Ünal F, Aşkın A, Koca E,Yıldırır M, Bingöl MÜ. 2019. Mycelial compatibility groups, pathogenic diversity and biological control of Sclerotium rolfsii on turfgrass. Egyptian Journal of Biological Pest Control. vol 29: 2-7. doi: https://doi.org/10.1186/s41938-019-0144-6.

Yusnawan E, Inayati A, Baliadi Y. 2019. Isolation of antagonistic fungi from rhizospheres and its biocontrol activity against different isolates of soil borne fungal pathogens infected legumes. Biodiversitas Journal of Biological and Diversity. vol 20(7): 2048-2054. doi: https://doi.org/10.13057/biodiv/d200735.

Zhou JY, Zhao XY, Dai CC. 2014. Antagonistic mechanisms of endophytic Pseudomonas fluorescens against Athelia rolfsii. Journal of Applied Microbiology. vol 117(4): 1144-1158. doi: https://doi.org/10.1111/jam.12586. 